\title{
Collaborative Services: A Four-Level Model for Supply Chain Management with Big Data Technology
}

\author{
Yanxia $\mathrm{Lu}^{1,2, a}$, Tingbin Chen ${ }^{1, \mathrm{~b}}$, Jiacong Zhao ${ }^{1, \mathrm{c}}$ and Jingshu Wang ${ }^{1, \mathrm{~d}^{*}}$ \\ ${ }^{1}$ Dalian Neusoft University of Information, Department of Information Management, Dalian,China \\ ${ }^{2}$ Faculty of Management and Economics, Dalian University of Technology, Dalian,China \\ aluyanxia@neusoft.edu.cn, ${ }^{\mathrm{b}}$ chentingbin@neusoft.edu.cn, ${ }^{\mathrm{c}}$ zhaojiacong@neusoft.edu.cn, ${ }^{\mathrm{d}}$ wangjing \\ ahu@neusoft.edu.cn
}

Keywords: Big data; Supply chain; Collaborative services

\begin{abstract}
The accelerating development of information technology boosts the progress of Big Data, Cloud Computing and Internet of Things. Companies that involved in supply chains store vast amounts of structured and unstructured data which are inherently difficult to maintain, expand and collaborate. This hampers the cost control and risk management of supply chain. Taking equipment manufacturing industry as the study background and cooperating with integrating with supply chain collaborative requirements, this project designs a four-level expandable cloud platform for achieving collaborative services of supply chain and constructs the Collaborative Services Model through perspectives like sales, purchase and manufacturing etc.. This model realizes the valuable exchange that from data to information and then to knowledge, which reduces the cost and improves the competition of the company effectively.
\end{abstract}

\section{Introduction}

Recently, the accelerating development of information technology boosts the progress of Big Data, Cloud Computing and Internet of Things. People all over the world are experiencing data explosion. The widely use of Internet provides a mature environment for large sale and distributed data management, which stores and transforms these automatic generation data with relative low cost. In this situation, the potential value of Big Data is receiving increasingly attention from diverse fields. Techniques like data mining and data analysis are introduced to decision making.

The application of Big Data is gradually being a new economic growth point of China and this technology is widely used in supply chain. For example, camera, smart phone and personal computer are widely used by supply chain members. These intelligence devices store a great amount of structured and unstructured data which contains transactions data, time data, customer service data and location data etc. However, unstandardized progress, data and technologies bring significant difficulties to supply chain management in terms of achieving expandability, maintenance and collaboration. This hampers the cost control and risk management of supply chain. Continuously optimizing of supply chain management is one of the virtual strategies for companies to achieve the sustainable development.

In order to achieve the visuality, collaboration and optimization, this project takes equipment manufacturing industry as the study background and cooperates with integrating with supply chain collaborative requirements, this project designs a four-level expandable cloud platform for achieving collaborative services of supply chain and constructs the Collaborative Services Model through perspectives like sales, purchase and manufacturing etc.. This model realizes the valuable exchange that from data to information and then to knowledge, which reduces the cost and improves the competition of the company effectively.

\section{Related Work}

The Application of Big Data in Supply Chain Management Field. Volume, variety, velocity, veracity and value are five characteristics of big data. Appropriate storage and analysis of these data have 
been a productive approach for companies to optimize current operations and enhance their competition [1]. During the last decades, big data was widely applied and researched by scholars and currently been applied to various industries. With referencing to industry chain, Fang[2]analyzed the supply chain finance of e-business platforms which operated B2C tactics. This paper proposes novel services of supply chain finance for different financing objects in big data environment. $\mathrm{Wu}[3]$ proposed a three-level supply chain cooperation strategy model which contains retailer-pay contract, union-pay contract and cooperation contract. Lv[4] came up with a multiple evaluation model for renewable resources policy. Chen[5] analyzed the value and characteristics of information aggregation business pattern in supply chain operations, so as to demonstrate its value creation mechanism in big data area.

Previous work shows that acts as one of the last technologies, big data plays an important role in fields like in e-business, e-finance and supply chain. However, rare scholars propose models for catching, dealing and presenting supply chain data which is volume, structured and unstructured.

Current Collaborative Services Research of Supply Chain. A number of scholars work on collaborative services of supply chain. Long[6] studied the effect of suppliers, customers, cross-departments and collaboration ability to the innovation of enterprise. Additionally, the regulating effect of dynamic environment was analyzed. Gong[7]constructed a collaborative supply chain model under symmetric and asymmetric information situation. Based on game theory and comparative static analysis, Hou[8] researched the collaborative issues of a supply chain which is composed by a retailer and a supplier with promotion action. $\mathrm{Wu}[9]$ studied the phylogeny issues of the collaborative operation of a low carbon supply chain, and constructed the evolution model to deal with this issue with referencing rate principle of dynamic systems. Under the limited information sharing condition, $\mathrm{Du}[10]$ introduced concession negotiation strategy to construct the supply chain produce-sale collaborative planning conflict negotiation model and prove the availability of Cultural Genetic Algorithm and Conflict Negotiation Algorithm by example simulation.

Previous work constructed supply chain collaborative and evolving models with theories like dynamic systems, game theory and genetic algorithm. Simulations for theory and application had been done theoretically and methodologically. However, current research shows that rare job has focused on solving supply collaboration, manufacturing collaboration and collaborative services of supply chain systematically.

\section{The expandable four-level supply chain collaborative services model}

Collaborative Services of Manufacturing Supply Chain.The collaborative services process contains various enterprises, such as core enterprise (refers to equipment manufacturing enterprises), suppliers, distributers, retailers, the third-party logistics. Collaborative operation is a complex interchange process between internal and external systems of companies. In this big data era, mature Internet environment and ubiquitous intelligence devices, such as sensor, camera, smart phone and personal computer, enable members of a supply chain to share information effectively. The supply chain collaborative services include sales, purchase, design and manufacturing. The collaborative management of these operations introduces big data technology to analyze and deal with the data related to raw materials, semi-products, products and final products' data collection and transmission. This situation requires the construction of a specific manufacturing oriented expandable big data model.

Cloud based Collaborative Services Model.This project based on scenario analysis to acquire the requirements of supply chain collaborative services, based on big data technology, design an expandable cloud based four-level supply chain collaborative services model. Specifically, data obtaining level, data dealing level, data exhibiting level and collaborative services level.

(1) Data obtaining level: This is the data resources of supply chain. It is for data perception and acquisition by using sensor, RFID, moving devices, cameras, GPS and Internet, Internet of Things, Internet of Cars. This level comprehensively integrates perceptions and acquires diverse information of manufacturing industry, and stores information into database like SQL, NoSQL, MPP and HANA。

(2) Data dealing level: This level analyzes and deals with data transparently. Additionally, 
reconstructing, cleaning and integrating structured and unstructured data. With referencing to the big data theoretical background, adopting Hadoop to construct big data platform based on 'low-level configuration' devices, so as to analyze and deal with heterogeneity and non-heterogeneity.

(3) Data exhibiting level: In order to meet the specific requirement of big data, a cloud based big data storage system should be constructed. The volume characteristics of big data can be achieved by stablishing the public information cloud, basic service cloud, value-added service cloud and storage supply chain requirements predict services, product innovation services, call services of resources. Additionally, providing an exhibit platform for structured, semi-structured and unstructured big data.

Collaborative services level: Web services are provided by this level, such as Web services calling, Web services discovering and matching, Web services grouping. Establishing a model based on Web services grouping and supply chain application. This realizes the intelligent search of Web services, so as to support calling and grouping of Web services, and exchanging information to contents for providing service. See Fig.1.

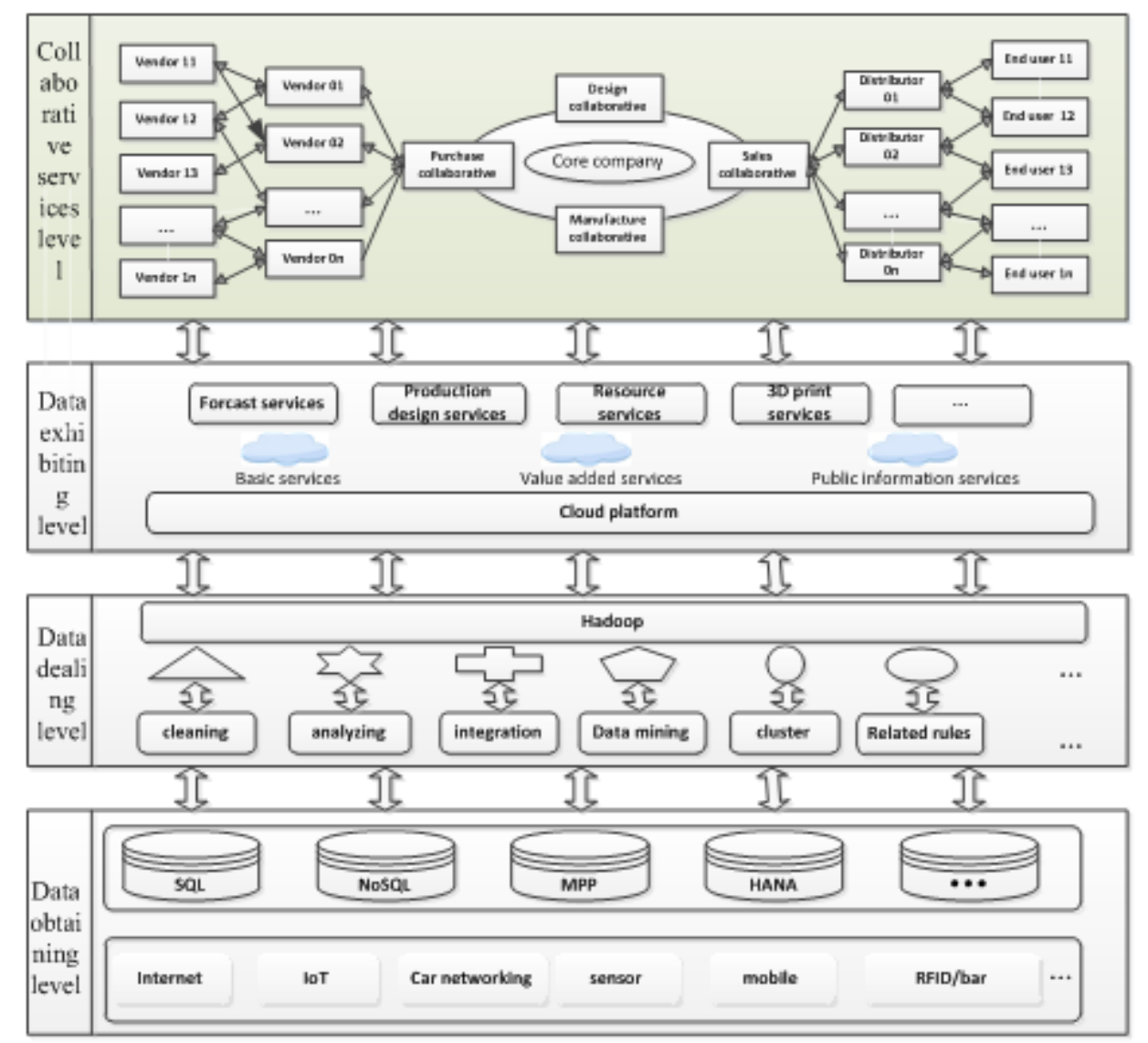

Figure 1. Four-Level Collaborative Services Model

\section{Analysis of Core Supply Chain Collaborative Services}

Sales Collaborative Services. The sales management of a company mainly contains price, order, delivery and customer information. Operation objects include materials, customer record, price, order, delivery and related receipts, data and graph. Sales procedures include price, order, delivery, package, receipt and payment. Each operation is composed by fine-grained services, and every fine-gained service takes data access logic component to conduct data search, update and store. Sales Collaborative Services is shown in table. 1 
Table 1 Sales Collaborative Services

\begin{tabular}{|c|c|c|c|}
\hline $\begin{array}{l}\text { Sales } \\
\text { Procedures }\end{array}$ & $\begin{array}{l}\text { Collaborative } \\
\text { Services Activities }\end{array}$ & $\begin{array}{l}\text { Collaborative Services } \\
\text { Functions }\end{array}$ & $\begin{array}{l}\text { Collaboration } \\
\text { Type }\end{array}$ \\
\hline \multirow{2}{*}{$\begin{array}{l}\text { Core customer } \\
\text { database }\end{array}$} & $\begin{array}{l}\text { Adding customer } \\
\text { information }\end{array}$ & $\begin{array}{l}\text { Establishing new customer } \\
\text { record based on the provided } \\
\text { information }\end{array}$ & External \\
\hline & $\begin{array}{l}\text { Maintaining and } \\
\text { updating customer } \\
\text { information }\end{array}$ & Editing customer information & Internal \\
\hline \multirow{2}{*}{ Sales price } & $\begin{array}{l}\text { Establishing price } \\
\text { sheet }\end{array}$ & $\begin{array}{l}\text { Negotiating and pricing } \\
\text { based on customer } \\
\text { requirements }\end{array}$ & External \\
\hline & $\begin{array}{l}\text { Generating orders } \\
\text { based on pricing sheet }\end{array}$ & $\begin{array}{l}\text { Creating orders based on } \\
\text { price sheet }\end{array}$ & Internal \\
\hline \multirow{2}{*}{ Orders } & Order establishment & $\begin{array}{l}\text { Creating sales order based on } \\
\text { customer orders }\end{array}$ & External \\
\hline & Order changing & $\begin{array}{l}\text { Order editing based on } \\
\text { customer requirements }\end{array}$ & External \\
\hline \multirow{3}{*}{ Delivery } & $\begin{array}{l}\text { Establishing delivery } \\
\text { order }\end{array}$ & $\begin{array}{l}\text { Creating delivery order based } \\
\text { on customer requirement and } \\
\text { inventory }\end{array}$ & External \\
\hline & Picking & Picking list generation & Internal \\
\hline & $\begin{array}{l}\text { Packaging and } \\
\text { delivering }\end{array}$ & $\begin{array}{l}\text { Packing and delivering based } \\
\text { on customer requirements }\end{array}$ & Internal \\
\hline \multirow[t]{2}{*}{ Payment } & Receipt & $\begin{array}{l}\text { Generating receipt lists } \\
\text { regularly and giving receipts } \\
\text { to customer }\end{array}$ & External \\
\hline & Receipt delivery & Record the payment & Internal \\
\hline Sales analysis & Sales data analysis & $\begin{array}{l}\text { Business analysis based on } \\
\text { the sales data }\end{array}$ & Internal \\
\hline
\end{tabular}

Procurement Collaborative Services. The purchase management of a company should cooperate closely with the up-stream supplies. Supply chain management system can response customer in timely manner and reduce inventory cost by collaborating the internal organizations of a company and external purchase procures. Procurement Collaborative Services should complete the whole functions of a purchase procedure. For instance, suppliers interchange and management collaborative services, trade matching collaborative services, procurement contract collaborative services, inventory and supply chain management collaborative services, material data and information searching collaborative services. Procurement Collaborative Services is shown in Table 2

Manufacture Collaborative Services.The manufacturing department of a supply chain should closely cooperate with its down-stream company, so as to achieve manufacture planning and produce controlling effectively. In order to realize the synchronization of a manufacturing in a supply chain, a transparency working mechanism should be established between companies. The supply chain manufactures are changing from hierarchical control organization mode to flat network organization. In order to realize the Internet based collaboration management, the whole manufacturing process should include product collaboration services, manufacturing planning services, outsourcing processing services, order dealing services. Manufacture Collaborative Services is shown in Table. 3. 
Table 2 Procurement Collaborative Services

\begin{tabular}{|c|c|c|c|}
\hline $\begin{array}{l}\text { Procurement } \\
\text { Collaborativ } \\
\text { e Services }\end{array}$ & $\begin{array}{l}\text { Collaborative } \\
\text { Services } \\
\text { Activities } \\
\end{array}$ & $\begin{array}{l}\text { Collaborative Services } \\
\text { Functions }\end{array}$ & $\begin{array}{l}\text { Collaboratio } \\
\text { n Type }\end{array}$ \\
\hline \multirow{2}{*}{$\begin{array}{l}\text { Suppliers } \\
\text { management }\end{array}$} & $\begin{array}{l}\text { Adding and } \\
\text { evaluating new } \\
\text { suppliers }\end{array}$ & $\begin{array}{l}\text { Establishing new supplier } \\
\text { record based on the provided } \\
\text { information }\end{array}$ & External \\
\hline & $\begin{array}{l}\text { Maintaining } \\
\text { existed suppliers }\end{array}$ & $\begin{array}{l}\text { Editing existed supplies } \\
\text { information }\end{array}$ & Internal \\
\hline \multirow{2}{*}{$\begin{array}{l}\text { Procurement } \\
\text { Planning } \\
\text { procedures }\end{array}$} & $\begin{array}{l}\text { Making purchase } \\
\text { planning }\end{array}$ & \begin{tabular}{llr} 
Generating & \multicolumn{2}{c}{ procurement } \\
planning & based & on \\
manufacturing department &
\end{tabular} & Internal \\
\hline & $\begin{array}{l}\text { Placing } \\
\text { Procurement order }\end{array}$ & $\begin{array}{l}\text { Delivering procurement } \\
\text { planning to supplier }\end{array}$ & External \\
\hline \multirow{3}{*}{$\begin{array}{l}\text { Pricing } \\
\text { negotiation }\end{array}$} & Price enquire & Enquiring price from supplier & External \\
\hline & $\begin{array}{l}\text { Suppliers provide } \\
\text { price information }\end{array}$ & $\begin{array}{lll}\begin{array}{l}\text { Suppliers } \\
\text { information }\end{array} & \text { provide } & \text { price } \\
\end{array}$ & External \\
\hline & Price dealing & $\begin{array}{l}\text { Choosing and informing the } \\
\text { appropriate supplier }\end{array}$ & External \\
\hline \multirow{2}{*}{$\begin{array}{l}\text { Procurement } \\
\text { orders dealing } \\
\text { procedures }\end{array}$} & $\begin{array}{l}\text { Creating } \\
\text { procurement order }\end{array}$ & $\begin{array}{l}\text { Creating procurement order } \\
\text { based on the provided price }\end{array}$ & Internal \\
\hline & $\begin{array}{l}\text { Giving the orders } \\
\text { to supplier }\end{array}$ & Placing order & External \\
\hline \multirow{3}{*}{$\begin{array}{l}\text { Products } \\
\text { Receiving } \\
\text { procedures }\end{array}$} & $\begin{array}{l}\text { Receiving the } \\
\text { delivery } \\
\text { information }\end{array}$ & $\begin{array}{l}\text { Receiving the delivery } \\
\text { information }\end{array}$ & External \\
\hline & $\begin{array}{l}\text { Checking and } \\
\text { putting in the } \\
\text { inventory }\end{array}$ & $\begin{array}{l}\text { Checking and putting in the } \\
\text { inventory }\end{array}$ & Internal \\
\hline & $\begin{array}{l}\text { Returning } \\
\text { management }\end{array}$ & $\begin{array}{l}\text { Returning the 'bad quality' } \\
\text { goods }\end{array}$ & External \\
\hline \multirow[b]{2}{*}{ Payment } & Checking receipt & Checking receipt & External \\
\hline & $\begin{array}{l}\text { Sending the receipt } \\
\text { to accounting } \\
\text { department }\end{array}$ & $\begin{array}{l}\text { Sending the receipt to } \\
\text { accounting department and } \\
\text { making payment }\end{array}$ & Internal \\
\hline $\begin{array}{l}\text { Procurement } \\
\text { analysis } \\
\text { procedures }\end{array}$ & $\begin{array}{l}\text { Procurement data } \\
\text { analysis }\end{array}$ & $\begin{array}{l}\text { Business analysis based on the } \\
\text { procurement data }\end{array}$ & Internal \\
\hline
\end{tabular}

\section{Conclusion}

This project takes equipment manufacturing industry as the study background and cooperates with integrating with supply chain collaborative requirement scenarios, designing a four-level expandable cloud platform for achieving collaborative services of supply chain. Additionally, this project analyzes the core procedures sales, purchase and manufacturing of a company. The proposed four-level collaborative services model realizes the value exchange of a company. It enables a company to overcome the region and organization limitations and achieve a more productive communication between cross-companies and cross-regions. This model significantly decrease operation cost and improve the competitiveness of companies. The future work will mainly focus on the achievement of the intelligent technologies of supply chain collaborative services, evaluation criteria for the proposed collaborative services model, data processing of collaborative services. A more productive supply chain collaborative services procedure will be established. 
Table 3 Manufacture Collaborative Services

\begin{tabular}{|c|c|c|c|}
\hline $\begin{array}{l}\text { Manufacture } \\
\text { Collaborative } \\
\text { Services }\end{array}$ & $\begin{array}{l}\text { Collaborative } \\
\text { Services } \\
\text { Activities }\end{array}$ & Collaborative Services Functions & $\begin{array}{l}\text { Collaboration } \\
\text { Type }\end{array}$ \\
\hline \multirow{2}{*}{$\begin{array}{l}\text { product } \\
\text { collaboration } \\
\text { services }\end{array}$} & $\begin{array}{l}\text { Requirement } \\
\text { management }\end{array}$ & $\begin{array}{l}\text { Customer new requirements } \\
\text { recognizing and extracting }\end{array}$ & External \\
\hline & $\begin{array}{l}\text { Product data } \\
\text { management }\end{array}$ & $\begin{array}{l}\text { Product design and creating and } \\
\text { updating the information of new } \\
\text { products }\end{array}$ & Internal \\
\hline \multirow{4}{*}{$\begin{array}{l}\text { manufacturing } \\
\text { planning } \\
\text { services }\end{array}$} & $\begin{array}{l}\text { Operations of } \\
\text { MPS and MRP }\end{array}$ & Generating MPS and MRP & Internal \\
\hline & $\begin{array}{l}\text { Deriving } \\
\text { procurement } \\
\text { planning }\end{array}$ & $\begin{array}{l}\text { Deriving procurement planning for } \\
\text { components }\end{array}$ & External \\
\hline & $\begin{array}{l}\text { Deriving } \\
\text { manufacturing } \\
\text { planning } \\
\end{array}$ & $\begin{array}{l}\text { Generating manufacturing planning } \\
\text { for components with enough } \\
\text { resources and capabilities }\end{array}$ & Internal \\
\hline & $\begin{array}{l}\text { Deriving } \\
\text { outsourcing } \\
\text { planning }\end{array}$ & $\begin{array}{l}\text { Outsourcing the components that } \\
\text { cannot be produced and making } \\
\text { planning for them }\end{array}$ & External \\
\hline \multirow{3}{*}{$\begin{array}{l}\text { manufacturing } \\
\text { coordinating } \\
\text { services }\end{array}$} & $\begin{array}{l}\text { Usability } \\
\text { checking }\end{array}$ & $\begin{array}{l}\text { Usability checking for materials } \\
\text { within the manufacturing planning }\end{array}$ & External \\
\hline & $\begin{array}{l}\text { Unavailability } \\
\text { checking }\end{array}$ & $\begin{array}{l}\text { Checking the unavailability of the } \\
\text { manufacturing process }\end{array}$ & Internal \\
\hline & $\begin{array}{l}\text { Planning } \\
\text { rearrangement }\end{array}$ & $\begin{array}{l}\text { Rearranging the amount, time, } \\
\text { configuration and materials of the } \\
\text { planning. }\end{array}$ & Internal \\
\hline \multirow{4}{*}{$\begin{array}{l}\text { outsourcing } \\
\text { processing } \\
\text { services }\end{array}$} & $\begin{array}{l}\text { Signing the } \\
\text { outsourcing } \\
\text { contract }\end{array}$ & $\begin{array}{l}\text { Signing the outsourcing contract } \\
\text { with appropriate company }\end{array}$ & External \\
\hline & Tracking & Tracking the whole process & External \\
\hline & $\begin{array}{l}\text { In/out } \\
\text { inventory }\end{array}$ & Quality guarantee & External \\
\hline & payment & Pay the outsourcing company & External \\
\hline \multirow{3}{*}{$\begin{array}{l}\text { order dealing } \\
\text { services }\end{array}$} & $\begin{array}{l}\text { Manufacturing } \\
\text { orders }\end{array}$ & $\begin{array}{l}\text { Arranging manufacturing and } \\
\text { generating order }\end{array}$ & Internal \\
\hline & $\begin{array}{l}\text { Order } \\
\text { implementation }\end{array}$ & Product manufacture & Internal \\
\hline & Inventory & Inventory for transportation & Internal \\
\hline $\begin{array}{l}\text { Manufacture } \\
\text { data analysis }\end{array}$ & $\begin{array}{l}\text { Manufacture } \\
\text { data analysis }\end{array}$ & $\begin{array}{l}\text { Cost analysis based on manufacture } \\
\text { data }\end{array}$ & Internal \\
\hline
\end{tabular}

\section{References}

[1] LIANG Hong-bo. Big-data-oriented cloud logistics leads the logistics mode change[J]. China Business and Market. 2014, 28(5): 41-45. 
[2] FANG Xiu-li, WU Zhuo-liang. Supply chain financial services innovation based on B2C under the environment of bid-data[J]. Journal of Chongqing University of Science and Technology(Social Sciences Edition). 2016(07): 41-44.

[3] WU Cheng-xia, ZHAO Dao-zhi, PAN Xin-yu. Comparison on dynamic cooperation strategies of a three-echelon supply chain involving big data service provider [J]. Control and Decision. 2016(07): 1169-1177.

[4] LV Yan. Research on Renewable Energy Policy Evaluation Based on Supply Chain Coordination[J]. Management World. 2015(12): 180-181.

[5] CHEN Yong-ping, JIANG Ning.Performance mechanism of supply chain information aggregation value and value creation ability in large data age [J]. Information Theory and Practice. 2015(07): 80-85.

[6] Long Yong, Zhou Jing. Collaborative Ability and Its Influence in Supply Chain Collaborative Technology Innovation [J]. Soft Science. 2015(01): 47-52.

[7] Gong Daqing, Liu Shifeng.Study on the Influence of Information Condition Difference on Supply Chain Collaborative Management [J]. Soft Science.. 2015(05): 121-124.

[8] HOU Yumei, TIAN Xin, MA Li-jun, et al.Cooperation decision-making based on supplier promotion and sales effort [J] .Systems Engineering Theory \& Practice. 2013(12): 3087-3094. J. van der Geer, J.A.J. Hanraads, R.A. Lupton, The art of writing a scientific article, J. Sci. Commun. 163 (2000) 51-59.

[9] WU Yi-sheng. Evolution Model of Low Carbon Supply Chain Collaborative Operation [J].

[10] operation research and management science. 2014(02): 124-132.

[11] Du Tong, Jiang Guorui.Commercial production chain production and marketing collaborative planning conflict negotiation model [J]. Computer Engineering and Applications. 2014 (06): $265-270$. 